

Original Research Article

https://doi.org/10.20546/ijcmas.2017.608.403

\title{
Development of Orange (Citrus reticulate Blanco) Wine from Mixed Culture Fermentation
}

\author{
S.R. Patharkar ${ }^{*}$, D.K. Kawadkar ${ }^{2}$ and A.P. Khapre ${ }^{3}$ \\ ${ }^{1}$ College of Food Technology, Naigaon, Maharashtra, India \\ ${ }^{2}$ Department of Chemical Technology (Food Technology), Laxminarayan Institute of \\ Technology, Nagpur, Maharashtra, India \\ ${ }^{3}$ MIT College of Food Technology, Aurangabad (M.S.), India \\ *Corresponding author
}

\section{A B S T R A C T}

Keywords

Alcoholic

fermentation,

Alcoholic yeast

species, Ethanol,

Mixed culture,

Orange juice,

Wine.

Article Info

Accepted:

26 June 2017

Available Online:

10 August 2017
The present investigation was carried out for development of orange wine from mixed culture fermentation apart from single culture. Optimal fermentation parameters of orange juice fermentation were recorded at $27^{\circ} \mathrm{C}$ temperature, $\mathrm{pH} 4.5$ and total soluble solids of $24^{\circ} \mathrm{Brix}$ with an inoculum level of $10 \%(\mathrm{v} / \mathrm{v})$. The fermentation of the fruit juice was completed within 7 days. A maximum ethanol content of $8.5 \%(\mathrm{v} / \mathrm{v})$ from monoculture and $8.1 \%(\mathrm{v} / \mathrm{v})$ from mixed culture was detected in the orange wine under optimized conditions. Mixed culture fermentation incorporating S. cerevisiae and $S$. cerevisiae var. ellipsoideus permitted the modulation of yeast growth and ensured completion of the fermentation. Orange wine produced by monocultures of $S$. cerevisiae and $S$. cerevisiae var. ellipsoideus had distinct aroma characteristics.

\section{Introduction}

The conversion of raw food materials into finished fermented products is often considered to be one of the best examples of "value added" processing. Indian wine exports are going up every year in the world and spread very fast with creating awareness of Indian wines in international market. Wine has been evaluated to be able to impart better organoleptic quality by pure Saccharomyces cerevisiae.

Mixed-culture fermentations are those in which the inoculum always consists of two or more organisms. Mixed cultures can consist of known species to the exclusion of all others, or they may be composed of mixtures of unknown species (Imma et al., 2009). The mixed cultures may be all of one microbial group like all bacteria's or they may consist of a mixture of organisms of fungi and bacteria or fungi and yeasts or other combinations in which the components are quite unrelated. All of these combinations are encountered in desirable food fermentations. Generally, the use of suitable yeast culture can be employed to enhance desirable flavor compounds while maintaining the fermentation reliability not only for grape 
wine but also for other fruit wines such as pineapple, pomegranate, apple etc. Citrus is most commonly consumed fruit as a good source of vitamin $\mathrm{C}$ and other nutrients (Khandelwal et al., 2006). Oranges are grown all over the world. In Asia, it is most abundantly grown in Japan, southern China and India. Mandarin is very important fruit crop, second only to banana. It is usually consumed in raw form or in fruit salads as well as juice so present work has been carried out to investigate the suitability of orange juice for the production of wine (Rajendra, 2009).

In present investigation attempts were also made to prepare the wine from mixed culture with the objectives like, to check the influence of mixed culture on orange juice for the preparation of wine, to compare the results of orange wine from mixed culture and mono culture fermentation of orange juice and to optimize the conditions of fermentation of mixed culture.

\section{Materials and Methods}

\section{Oranges}

Orange variety 'Nagpur Santra' (Citrus Reticulata Blanco) was used in the study was purchased from the local market of Nagpur. Fresh ripened oranges were washed with water, peeled and juice was extracted using the screw press juice extractor.

\section{Pretreatment of orange juice}

The degree brix $\left({ }^{0} \mathrm{Bx}\right)$ of the orange juice was raised as required by adding sugar. $\mathrm{pH}$ was adjusted by adding a saturated solution of sodium bicarbonate. Then, it was pasteurized and allowed to cool to room temperature

\section{Cultures}

For the fermentation process, yeast strain Sacchromyces cerevisiae (No. 3282) and
(Saccharomyces cerevisiae var. ellipsoideus) (No. 3215) were obtained from National Chemical laboratory, Pune.

\section{Preparation of broth}

The broth media was prepared in 250 distilled water consisting of $0.75 \mathrm{~g}$ malt extract, $2.5 \mathrm{~g}$ glucose, $0.75 \mathrm{~g}$ yeast extract and $1.25 \mathrm{~g}$ of peptone. This media was sterilized and divided into different flasks to maintain a volume of $30 \mathrm{ml}$ then inoculated with the yeast strain and kept for incubation at $27^{\circ} \mathrm{C}$ for a day and then stored at low temperature (Garcia et al., 2006).

\section{Experimental setup and procedure}

\section{Batch fermentation set up}

$500 \mathrm{ml}$ of pasteurized orange juice of $24^{0}$ Brix was taken in $1000 \mathrm{ml}$ conical flask and broth media is added under sterile conditions.

Fermentation is carried out at $27^{\circ} \mathrm{C}$ under anaerobic condition with arrangement for $\mathrm{CO}_{2}$ to escape. After completion of fermentation the wine was filtered, centrifuged and filled in glass bottles (Flow sheet 1) (Robert, 2006).

\section{Total soluble solids (TSS)}

The total soluble solid content was determined in terms of degree brix by using hand refractometer at $20^{\circ} \mathrm{C} \quad\left(68^{\circ} \mathrm{F}\right)$. It measures TSS in terms of refractive index. Brix is a measure of solids only in case of pure sucrose solutions. Generally, fruit juices contain more sugar than any other soluble constituents and hence brix provides a useful guide of soluble solid or sugar content (Maziar, 2006).

\section{pH}

The $\mathrm{pH}$ of juice was measured by using electronic digital pH meter (Ranganna, 1986). 


\section{Acidity}

The known quantity of sample was taken. Water was added to it and mixed thoroughly, finally made up to known volume. Then known amount of that extract was titrated with $0.1 \mathrm{~N} \mathrm{NaOH}$ using few drops of $1 \%$ phenolphthalein solution as indicator. The titre value was noted. The results were calculated as percent citric acid, as $1 \mathrm{ml}$ of 0.1 $\mathrm{N} \mathrm{NaOH}=0.0064$ g citric acid (Ranganna, 1986).

$(0.0064 \times \mathrm{N}$ of $\mathrm{NaOH} \times$

Volume made up $\times$ B.R. $\times 100$ )

$\%$ Acidity $=$

(Volume of sample taken $x$

Weight of sample $\times 1000$ )

\section{Ascorbic Acid}

Reagents required for estimation of ascorbic acid content:

$3 \%$ Metaphosphoric acid $\left(\mathrm{HPO}_{3}\right)$ acetic acid solution was prepared by dissolving $15 \mathrm{~g}$ metaphosphoric acid in mixture containing $450 \mathrm{ml}$ water and $40 \mathrm{ml}$ glacial acetic acid.

Ascorbic acid standard: Accurately $0.05 \mathrm{gm}$ of L-ascorbic acid was weighed and made to $250 \mathrm{ml}$ with metaphosphoric acetic acid solution.

Dye solution: $0.05 \mathrm{~g}$ of the sodium salt of 2, 6-dichlorophenol-indophenol dye and $0.04 \mathrm{~g}$ sodium bicarbonate was dissolved in $200 \mathrm{ml}$ water. Filtered it and stored in dark coloured bottle at refrigerated condition.

\section{Standardization of dye}

$10 \mathrm{ml}$ of standard ascorbic acid solution was transferred to the titration flask. Burette was filled with dye solution and titration was carried out till pink colour was persisted for $15 \mathrm{~s}$.
Then, the dye factor was determined i.e. $\mathrm{mg}$ of ascorbic acid per $\mathrm{ml}$ of the dye using following formula:

Dye Factor $=0.25 \times 10 /$ Titre

Titration of sample: $10-20 \mathrm{ml}$ of sample was taken and titrated against dye solution to a pink colour, which should persist for $15 \mathrm{~s}$ and this burette reading was noted (Ranganna, 1986).

(Titre $x$ Dye factor $x$

Volume made up $\times 100$ )

Ascorbic acid $(\mathrm{mg} / \%)=$

(Weight of sample $x$ Volume of sample taken)

\section{Juice yield}

The percent yield of juice was calculated on the basis of weight of total weight of fruits (Nikhil et al., 2009).

Percent yield $=($ Weight of juice $) /($ Total weight of fruit) $\times 100$

\section{Juice clarity}

The clarity of the juice obtained was determined by measuring the absorbance at a wavelength of $660 \mathrm{~nm}$ using UV-VIS spectrophotometer. Distilled water was used as the reference.

\section{Specific gravity}

The specific gravity was determined using specific gravity bottle. The empty bottle was weighed, filled with distilled water and reweighed. It was then filled with sample and weighed (Ranganna, 1986).

The specific gravity, of the sample was calculated, as follows:

Specific Gravity $=$ Ws $/ \mathrm{Ww}_{\mathrm{w}}$ 
Where,

$\mathrm{W}_{\mathrm{s}}=$ Weight of known volume of sample in $\mathrm{gm}$

$\mathrm{W}_{\mathrm{w}}=$ Weight of an equal volume of water in $\mathrm{gm}$

The density, $\rho$ in $\mathrm{kg} / \mathrm{m} 3$, was calculated as: $\rho=1000 \times$ Specific gravity

\section{Alcohol (Ethanol)}

Alcohol was estimated volumetrically by oxidation method (Okunowo et al., 2007).

\section{Apparatus}

Micro-Kjeldahl distillation apparatus.

\section{Reagents}

Potassium dichromate solution: 33.678 gm of $\mathrm{K}_{2} \mathrm{Cr}_{2} \mathrm{O}_{7}$ was dissolved in distilled water and diluted to $1000 \mathrm{ml}$.

Ferrous ammonium sulphate solution: 135.5 gm of $\mathrm{FeSO}_{4}\left(\mathrm{NH}_{4}\right)_{2} \mathrm{SO}_{2} .6 \mathrm{H}_{2} \mathrm{O}$ was dissolved in $500 \mathrm{ml}$ distilled water containing $20 \mathrm{ml}$ of conc. $\mathrm{H}_{2} \mathrm{SO}_{4}$ and diluted to $1000 \mathrm{ml} .2 \mathrm{ml}$ of this solution was equivalent to $1 \mathrm{ml}$ of the potassium dichromate solution when first made up but because its titer slowly decreases, it must be compared daily with $\mathrm{K}_{2} \mathrm{Cr}_{2} \mathrm{O}_{7}$ solution.

Barium diphenylamine sulfonate indicator: $0.5 \mathrm{gm}$ of Ba-diphenylamine sulfonate was dissolved in $100 \mathrm{ml}$ distilled water and filtered.

\section{Procedure}

\section{Distillation}

$25 \mathrm{ml}$ of sample was steam distilled in MicroKjeldahl flask. Steam was introduced and the distillate was collected through the condenser in the $250 \mathrm{ml}$ volumetric flask containing 100 $\mathrm{ml}$ distillled water. The volume was made up to $250 \mathrm{ml}$.

\section{Oxidation and titration}

$20 \mathrm{ml}$ of potassium dichromate solution was taken into a $1000 \mathrm{ml}$ glass stoppered flask and $10 \mathrm{ml}$ of concentrated sulfuric acid was added. Flask was agitated and cooled under running water at the room temperature. $10 \mathrm{ml}$ of distillate was added with gentle swirling and stoppered tightly. It was allowed to stand for $15 \mathrm{~min} .325 \mathrm{ml}$ of distilled water and 35 $\mathrm{ml}$ of $85 \%$ orthophosphoric acid and $1 \mathrm{ml}$ of indicator were added sequentially, mixed and titrated with the ferrous ammonium sulfate solution till the colour changed from blue violet to light green. The $\%$ of alcohol was calculated by the volume in the sample. Oxidation of $10 \mathrm{ml}$ distilled water was carried out as above and the titration reading was taken as blank.

( $\mathrm{ml}$ of distillate collected)

$\%$ of alcohol = $20(1-\mathrm{S} / \mathrm{B}) \mathrm{x}$-------

( $\mathrm{ml}$ of distillate oxidized $\mathrm{x}$ $\mathrm{ml}$ of sample distilled)

$\mathrm{S}=$ volume of reducing solution used

$\mathrm{B}=$ volume of reducing solution equivalent to $20 \mathrm{ml}$ of the std. $\mathrm{K} 2 \mathrm{Cr} 2 \mathrm{O} 7$ solution.

Where $25 \mathrm{ml}$ of sample have been distilled to $250 \mathrm{ml}$ and $10 \mathrm{ml}$ of the distillate has been oxidized. This reduces the formula to, volume $\%$ of alcohol $=20(1-\mathrm{S} / \mathrm{B})$

\section{Results and Discussion}

\section{Physico-chemical characterization of orange juice}

Physico-chemical characteristics of the juice are as follows: Total solids, $\mathrm{pH}$, acidity, 
ascorbic acid, juice yield, clarity and specific gravity were examined as $11.4{ }^{\circ} \mathrm{Bx}, 3.4$, $0.63 \%, 35 \mathrm{mg}, 45 \%, 0.278 \%$ and 1.014 , respectively in orange juice. Total sugars and total acids are the two main factors which are considered for the production of wine from any fruit juice. The amount of fermentable sugars and acid content adjusted in the orange juice made suitable for its use in making wine. It has been reported that orange juice contains very high amount of vitamin $\mathrm{C}$ as compared to other fruit juices. Oranges are less expensive as compared to other fruits. Moreover, ascorbic acid present in juice as natural antioxidant aid to increase shelf-life of juice.

Screening of yeast strains for fermentation of orange juice for wine

The amount of ethanol produced from orange juice by different strains of $S$. cerevisiae was quite variable. S. cerevisiae 3282 screened $S$. cerevisiae var. ellipsoideus 3215 for alcoholic fermentation of orange juice. S. cerevisiae showed the maximum $(8.5 \%, \mathrm{v} / \mathrm{v})$ of monoculture and $S$. cerevisiae var. ellipsoideus and $S$. cerevisiae showed less $(8.1 \%, \mathrm{v} / \mathrm{v})$ of mixedculture production of ethanol for wine. These strains were, therefore, selected for further studies. The fermentation potential of each organism varies from strain to strain and also depends upon the type of the substrate used for fermentation.

Optimization of orange wine with total soluble solids as fermentation condition

The total soluble solids of the orange juice were varied from $22-26\left({ }^{\circ} \mathrm{Bx}\right)$, to study its influence on fermentation of juice to develop wine. An increase in ethanol production was recorded with the increase in total soluble solids up to $24^{\circ} \mathrm{Bx}$ and thereafter, no change was recorded for this parameter (Figure 1) in monoculture as well as in mixed culture. Therefore, $24^{\circ} \mathrm{Bx}$ was considered optimal for further experimentation. The maximum ethanol production has been reported in juice with $24^{\circ} \mathrm{Bx}$ after 7 days of orange juice adjusted. The $\mathrm{pH} 4.5$ has been reported optimal for alcoholic fermentation of orange juice to develop orange wine.

\section{Optimization of orange wine with $\mathrm{pH}$ as fermentation condition}

The $\mathrm{pH}$ of the orange juice was varied from 4 to 5, to study its influence on fermentation of juice to develop wine. An increase in ethanol production was recorded with the increase in $\mathrm{pH} 4.5$ and thereafter, no change was recorded for this parameter (Figure 2) in monoculture as well as in mixed culture fermentation Therefore, 4.5 was considered optimal for further experimentation. The maximum ethanol production has been reported in juice with $4.5 \mathrm{pH}$ after 7 days of orange juice adjusted as $8 \%$ and $7.7 \% \mathrm{v} / \mathrm{v}$ respectively in mono and mixed culture fermentation. Earlier also total solids $24^{\circ} \mathrm{Bx}$ has been reported optimal for alcoholic fermentation of orange juice to develop orange wine with mixed and mono culture fermentation.

\section{Optimization of orange wine with percent inoculum as fermentation condition}

The results presented in Figure 3 depict the effect of inoculum level of $S$. cerevisiae for monoculture and $S$. cerevisiae var. ellipsoideus and $S$. cerevisiae for mixed culture fermentation production of ethanol in orange juice. Ethanol production was increased with the increase in inoculums concentration up to $10 \%$ for a fermentation period of 7 days. A slight decrease in ethanol production was recorded beyond inoculum level of $10 \%$. An inoculum level of $10 \%$ has been optimized condition of fermentation. 
Fig.1 Optimization of orange wine with total soluble solids as fermentation condition for mono and mixed culture



(Fermentation conditions: Initial pH: 4.5; inoculum level: $10 \%$ (v/v); temperature: $27^{\circ} \mathrm{C}$; fermentation time: 7 days)

Fig.2 Optimization of orange wine with $\mathrm{pH}$ as fermentation condition for monoculture and mixed culture fermnetation



(Fermentation conditions: Total soluble solids: $24{ }^{\circ} \mathrm{Bx}$; inoculum size: $10 \%(\mathrm{v} / \mathrm{v})$; temperature: $27^{\circ} \mathrm{C}$; fermentation time: 7 days) 
Fig.3 Optimization of orange wine with percent inoculum as fermentation condition for mixed and monoculture fermentation

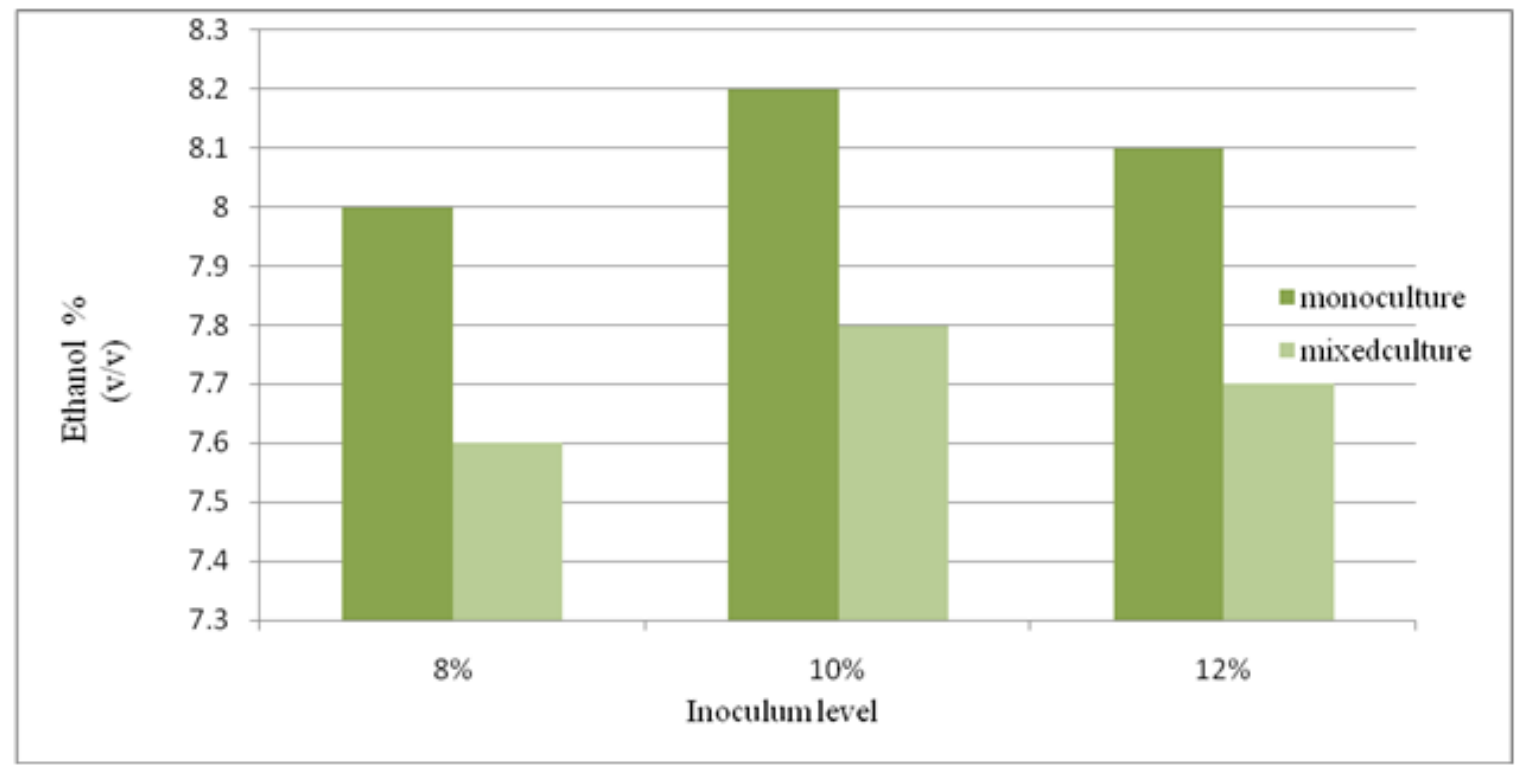

(Fermentation conditions: Total soluble solids: $24^{\circ} \mathrm{Bx}$; $\mathrm{pH} 4.5$; temperature: $27^{\circ} \mathrm{C}$; fermentation time: 7 days)

Fig.4 Optimization of orange wine with temperature as fermentation condition for mono and mixed culture fermentation

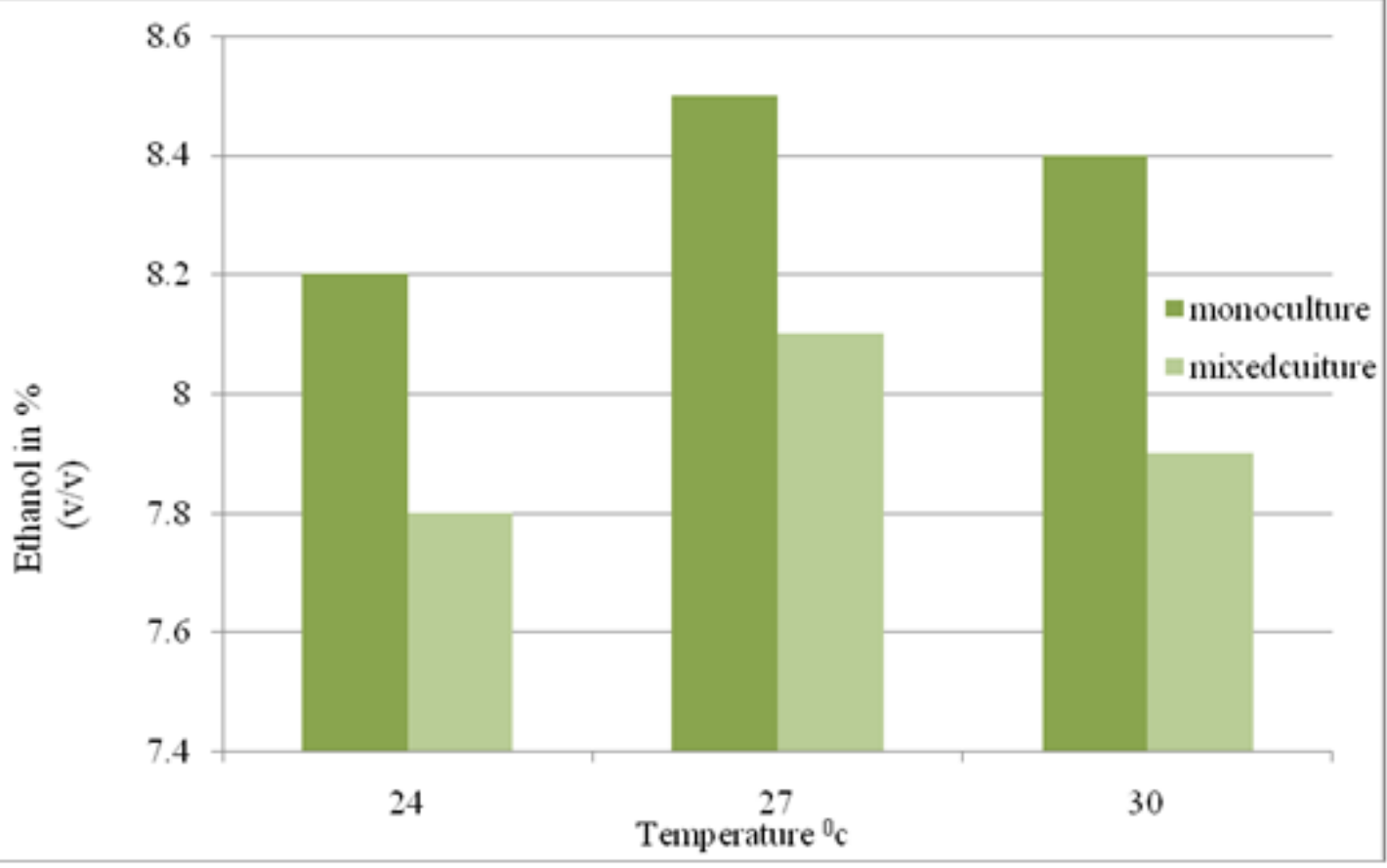

(Fermentation conditions: Total soluble solids: $24^{\circ} \mathrm{Bx}$; $\mathrm{pH}$ 4.5; inoculum 10\%; fermentation time: 7 days) 
Flow sheet.1 Flow diagram for the preparation orange wine



\section{Optimization of orange wine with} temperature as fermentation condition

Alcoholic fermentation orange juice was carried out for 7 days at a temperature range of $24-30^{\circ} \mathrm{C}$ for monoculture and mixed culture fermentation.

The maximum ethanol production was recorded at a temperature range of $27^{\circ} \mathrm{C}$ for both the monoculture and mixed culture fermentation depicted in Figure 4. Comparatively, ethanol production was lesser at $24^{\circ} \mathrm{C}$ and $30^{\circ} \mathrm{C}$ as compared to $27^{\circ} \mathrm{C}$ temperature. Therefore, a temperature of $27^{\circ} \mathrm{C}$ has been selected for further studies. Maximum ethanol production from orange juice has been reported at $27^{\circ} \mathrm{C}$ in both the fermentation mono and mixed culture.

\section{Sensory evaluation}

The sensory evaluation report reveals that the Orange wine was clean and of light yellow colour. It was having a good aroma of natural orange fruit. As compare to both the monoculture and mixed culture fermentation, mixed culture fermentation wine has distinct aroma with that of monoculture wines. In terms of the total score both the wines have been evaluated as of good quality.

As compare to both the monoculture and mixed culture fermentation, mixed culture fermentation wine has distinct aroma with that of monoculture wines. All samples of mixed cultures fermentations were good in terms of flavor as compare to monocultures wines. The high quality wines should have a 
characteristic bouquet and taste which depends on the cultivar, maturity and phytosanitary conditions of the fruit, climatic conditions and most importantly, on yeast fermentation physiology. All these factors cause the differences of aroma, fragrance, composition and quality among all kinds of fruit wines.

\section{References}

Garcia, V., H. Vasquez and F. Fonseca. 2006. Effects of using mixed wine yeast cultures in the production of Chardonnay wines. Revista Argentina de Microbiology, 42: 226-229.

Imma Andorra, Maria Berradre, Nicolas Rozes, Albert Mas and Jose M. Guillamon. 2009. Effect of pure and mixed cultures of the main wine yeast species on grape must fermentations. Department of Biotechnology, University of Rovira Tarragona, Spain.

Khandelwal Pratima, Kumar Vijay, Das Niranjan and Tyagi Surendra Mohan. 2006. Development of a process for preparation of pure and blended Kinnow wine without debittering Kinnow-Mandarin juice. Internet Journal of Food Safety, Vol. 8, pp. 2429.
Maziar Safaei Asli, 2010. A study on some efficient parameters in batch fermentation of ethanol using Saccharomyces cerevesiae SC1 extracted from fermented siahe sardasht pomace. African Journal of Biotechnology, Vol. 9 (20), pp. 29062912.

Nikhil Gupta, Soham Trivedi, Hipal Gaudani, Mayank Gupta, Prasad Patil and Girish Gupta. 2009. Orange: Research analysis for wine study. International Journal of Biotechnology Applications, Vol. 1, Issue 2, pp. 10-15.

Okunowo, Wahab Oluwanisola, Osuntoki and Akinniyi Adediran. 2007. Quantitation of alcohols in orange wine fermented by four strains of yeast. African Journal of Biochemistry Research, Vol. 1 (6), pp. 95-100.

Rajendra Kumar Tiwari, 2009. Post-harvest profile of Mandarin. Govt of India, Ministry of Agriculture.

Rangana, S., 1986. Handbook of Analysis and Quality control for fruit and vegetable products. II edn. Tata McGraw-Hill Publ. Co., New Delhi.

Robert W. Hutkins. 2006. Microbiology and technology of fermented foods. $\mathrm{I}^{\text {st }}$ edition, 2006.

\section{How to cite this article:}

Patharkar, S.R., D.K. Kawadkar and Khapre, A.P. 2017. Development of Orange (Citrus reticulate Blanco) Wine from Mixed Culture Fermentation. Int.J.Curr.Microbiol.App.Sci. 6(8): 3375-3383. doi: https://doi.org/10.20546/ijcmas.2017.608.403 